\title{
PENGARUH PENGGUNAAN CORN DRIED DISTILLERS GRAINS WITH SOLUBLES DALAM RANSUM TERHADAP PERFORMAN PUYUH JANTAN
}

\section{EFFECT OF UTILIZATION OF CORN DRIED DISTILLER GRAINS WITH SOLUBLES IN THE DIETS ON PERFORMANCE OF MALE COTURNIX}

\author{
Hestu Widyatmoko*, Zuprizal, dan Wihandoyo \\ Fakultas Peternakan, Universitas Gadjah Mada, Jl. Fauna No. 3, Bulaksumur, Yogyakarta, 55281
}

\section{INTISARI}

Feeding trial dilakukan untuk mempelajari pengaruh penggunaan corn dried distillers grains with solubles (DDGS) dalam pakan terhadap performan pertumbuhan puyuh jantan. Seratus dua puluh ekor puyuh jantan dibagi dalam empat kelompok perlakuan pakan dengan penggunaan DDGS sebanyak 0, 10, 20, dan 30\% menggunakan Rancangan Acak Lengkap. Pakan dan air minum diberikan secara ad libitum. Variabel yang diamati meliputi konsumsi pakan, rerata pertambahan bobot harian, dan feed conversion ratio. Data dianalisis variansi (ANOVA) menggunakan pola searah. Hasil penelitian menunjukkan bahwa penambahan DDGS dalam pakan tidak mempengaruhi konsumsi pakan, pertambahan bobot harian, dan feed conversion ratio puyuh jantan. Dapat disimpulkan dari penelitian ini bahwa DDGS dapat digunakan dalam ransum hingga level $30 \%$.

(Kata kunci: Performan pertumbuhan, Corn-DDGS, Puyuh jantan)

\section{ABSTRACT}

Feeding trial were conducted to study the effect of the use of corn dried distillers grains with solubles (DDGS) in the diets on growth performance of male coturnix. One hundred and twenty male coturnixs were allotted into four dietary treatments containing 0, 10, 20 and 30\% DDGS respectively in a Completely Randomized Design. Each treatment was replicated eight times. Feed and water were provided ad libitum. The variables observed were feed intake, average daily gain and feed conversion ratio. The data were analyzed using One Way of analyses of variance (ANOVA). The result indicated that there was no effect of DDGS on the feed intake, average daily gain and feed conversion ratio. It could be concluded that DDGS can be used up to $30 \%$ in the diets of male coturnix.

Keywords: Growth performance, Corn-DDGS, Male coturnix)

\section{Pendahuluan}

Burung puyuh adalah ternak kecil yang mempunyai potensi besar. Burung puyuh yang biasa dibudidayakan adalah berjenis kelamin betina untuk menghasilkan telur, sedangkan puyuh jantan yang tidak digunakan sebagai pejantan dapat dimanfaatkan sebagai ternak pedaging. Efisiensi burung puyuh pedaging untuk mengubah pakan menjadi daging memainkan peran kunci dalam perhitungan ekonomi industri unggas pedaging. Peningkatan efisiensi pakan burung puyuh ke depan sangat penting, untuk menghasilkan daging yang ekonomis. Semua unggas dan burung peliharaan diarahkan untuk menggunakan pakan lengkap, yang dirancang sehingga mengandung protein, energi, vitamin, mineral, dan nutrien lainnya sesuai dengan yang diperlukan untuk pertumbuhan, produksi telur dan kesehatan (Smith et al., 2003). Penggunaan bahan pakan kualitas tinggi sangat penting untuk

\footnotetext{
*Korespondensi (corresponding author):

Telp. +62 81392283028

Email: widyatmoko.h@gmail.com
}

menyusun pakan puyuh. Kualitas bahan pakan yang kurang baik mungkin dapat ditoleransi oleh beberapa tipe ternak, tetapi tidak untuk puyuh. Jika menggunakan bahan pakan yang berkualitas jelek, maka akan ditemukan masalah dalam produksi (Smith, 2011).

Corn dried distillers grains with solubles (Corn-DDGS) atau yang biasa disebut dengan DDGS merupakan limbah pembuatan etanol berbahan dasar jagung melalui proses fermentasi. Proses fermentasi yang terjadi pada jagung adalah proses perubahan pati jagung menjadi etanol dan $\mathrm{CO}_{2}$, sehingga komponen bahan lainnya seperti protein, lemak, serat, dan mineral akan diperoleh kembali dalam DDGS. Peningkatan permintaan ethanol dunia menyebabkan banyak pabrik didirikan untuk mensuplai permintaan pasar, dengan demikian akan semakin banyak pula DDGS yang dihasilkan.

Babcock et al. (2008) menyatakan bahwa DDGS masih potensial dan ekonomis untuk dimanfaatkan sebagai pakan ternak. Selain karena masih adanya kandungan protein dan lemak (Batal, 2009), DDGS bebas dari faktor beracun atau antinutrisi seperti gossypol di dalam biji kapas atau 
inhibitor trypsin dalam bungkil kedelai (Dale, 2007). Arora et al. (2008) melaporkan bahwa kandungan protein kasar dalam DDGS masih cukup tinggi, yaitu $30,8 \%$. Hal ini sangat menguntungkan dunia peternakan mengingat bahan tersebut merupakan limbah dan tidak bersaing dengan manusia.

Penelitian tentang DDGS pada ternak unggas telah banyak dilaporkan, diantaranya pada broiler (Khan et al., 2002; Wang et al., 2007), dan ayam layer (Shalash et al., 2010), sedangkan pada ternak puyuh belum pernah ada penelitian serupa. Berdasarkan uraian tersebut maka peneliti mencoba mengeksplorasi manfaat penggunaan DDGS terhadap performan puyuh jantan.

\section{Materi dan Metode}

Sebanyak 120 ekor puyuh jantan dengan berat rata-rata $8,03 \pm 0,04 \mathrm{~g}$ dibagi dalam empat perlakuan aras DDGS. Setiap perlakuan dibagi menjadi delapan kelompok sebagai replikasi dengan menggunakan lima ekor puyuh setiap replikasi. Perlakuan yang diujikan yaitu $\mathrm{P}_{0}=$ ransum tanpa DDGS, $\mathrm{P}_{1}=$ ransum dengan $10 \%$ DDGS; $\mathrm{P}_{2}=$ ransum dengan
20\% DDGS, dan $\mathrm{P}_{3}=$ ransum dengan 30\% DDGS. Semua ransum perlakuan disusun dengan protein kasar (PK), energi metabolisme (ME), asam amino (AA), $\mathrm{Ca}$, dan $\mathrm{P}$ tersedia, dengan basis rasio protein dan energi yang tetap (Tabel 1).

Pemeliharaan puyuh dilakukan sampai dengan 35 hari. Pencatatan data dimulai dari umur 15 hari. Minggu pertama dan kedua merupakan masa adaptasi dengan pakan dan kandang perlakuan. Peubah yang diukur dalam penelitian ini meliputi konsumsi pakan (g/ekor/hari), pertambahan bobot badan harian (g/ekor/hari), dan konversi pakan.

\section{Analisis data}

Data dianalisis statistik menggunakan analisis variansi Rancangan Acak Lengkap (RAL) pola searah dengan bantuan program Microsoft Excel.

\section{Hasil dan Pembahasan}

Performan pada unggas tipe pedaging dapat diamati melalui data bobot badan akhir, feed conversion ratio (FCR), konsumsi pakan, dan

Tabel 1. Komposisi dan kandungan nutrien pada pakan perlakuan (nutrient composition of feed treatment)

\begin{tabular}{lrrrr}
\hline \multirow{2}{*}{ Items } & \multicolumn{3}{c}{ Perlakuan (treatments) } \\
\cline { 2 - 5 } & \multicolumn{1}{c}{$\mathrm{P}_{1}$} & $\mathrm{P}_{2}$ & \multicolumn{1}{c}{$\mathrm{P}_{3}$} & $\mathrm{P}_{4}$ \\
\hline Komposisi bahan pakan (\%) (feedstuffs (\%)) & & & & \\
Jagung giling (corn meal) & 43,00 & 43,00 & 43,00 & 43,00 \\
Bekatul (rice bran) & 17,06 & 13,80 & 10,00 & 7,00 \\
Bungkil kedelai (soybean cake) & 26,80 & 21,12 & 15,87 & 10,90 \\
DDGS & - & 10,00 & 20,00 & 30,00 \\
Tepung ikan (fish meal) & 5,00 & 5,00 & 5,00 & 5,00 \\
Minyak kelapa sawit (crude palm oil) & 5,20 & 4,30 & 3,36 & 2,20 \\
Limestone & 1,20 & 0,80 & 0,80 & 0,00 \\
Dicalcium phosphate & 1,20 & 1,50 & 1,40 & 1,30 \\
L-Lysin HCl (98\%) & 0,10 & 0,10 & 0,20 & 0,30 \\
DL-Methionine (99\%) & 0,19 & 0,13 & 0,12 & 0,05 \\
Premik (premix) & 0,10 & 0,10 & 0,10 & 0,10 \\
Garam (salt) & 0,15 & 0,15 & 0,15 & 0,15 \\
Total & 100 & 100 & 100 & 100 \\
Kandungan nutrien (nutrient composition) & & & & \\
Energi metabolis (kcal/kg) (metabolizable energy (kcal/kg)) & 3068,65 & 3072,11 & 3071,39 & 3080,73 \\
Protein kasar (\%) (crude protein (\%)) & 20,78 & 20,38 & 20,24 & 20,28 \\
Ekstrak eter (\%) (extract ether (\%)) & 9,44 & 9,09 & 8,65 & 8,09 \\
Serat kasar (\%) (crude fiber (\%)) & 3,06 & 3,47 & 3,87 & 4,32 \\
Calcium (Ca) (\%) & 1,12 & 1,18 & 1,27 & 1,09 \\
Available phosphorus (Pav) (\%) & 0,52 & 0,56 & 0,53 & 0,50 \\
Metionin (\%) (methionine (\%)) & 0,47 & 0,43 & 0,45 & 0,41 \\
Lisin (\%) (lysine (\%)) & 1,17 & 1,09 & 1,10 & 1,12 \\
Triptofan (\%) (tryptophan (\%)) & 0,24 & 0,23 & 0,22 & 0,21 \\
\hline
\end{tabular}


mortalitas (Watkins et al., 2002; Khan et al., 2002; Smith et al., 2003). Pada akhir masa percobaan, bobot badan, konsumsi pakan total, dan efisiensi pakan dihitung (Tabel 2).

Penelitian menunjukkan bahwa penambahan DDGS hingga level 30\% tidak mempengaruhi performa puyuh jantan (Tabel 2). Dapat dikatakan bahwa corn-DDGS dapat digunakan sampai dengan $30 \%$ di dalam ransum puyuh jantan.

Faktor yang mempengaruhi berat badan dan FCR adalah konsumsi pakan, sedangkan faktor utama yang mempengaruhi konsumsi pakan pada unggas adalah kandungan energi pada ransum, semakin tinggi energi ransum maka konsumsi ransum akan menurun (Zuprizal, 2006). Keempat ransum perlakuan yang digunakan mempunyai kandungan energi yang hampir sama, yaitu rata-rata $3073,22 \pm 5,22 \mathrm{kcal} / \mathrm{kg}$ (Tabel 1). Hal ini menyebabkan tidak nampaknya perbedaan pada konsumsi pakan dari masing-masing perlakuan, yaitu rata-rata untuk $\mathrm{P}_{0}, \mathrm{P}_{1}, \mathrm{P}_{2}$ dan $\mathrm{P}_{3}$ berturut-turut adalah 284,47; 279,84; 291,29; dan 288,85 g/ekor atau rata-rata sebesar 13,62 $\pm 0,24 \mathrm{~g} /$ ekor/hari. Hal yang sama terjadi pada penelitian yang dilakukan Houndonougbo et al. (2009) yang mendapatkan konsumsi pakan ayam broiler yang juga tidak berbeda pada pakan perlakuan yang mempunyai kadar energi yang hampir sama (iso-energi). Hal ini diduga sebagai penyebab konsumsi pakan yang sama setiap hari pada puyuh dengan pakan perlakuan, dimana unggas secara umum mengatur konsumsi mereka terutama berdasarkan kandungan energi dari pakan (McDonald et al., 2002).

Kandungan serat kasar dalam ransum perlakuan yang juga hampir sama, yaitu rata-rata 3,68\% (Tabel 1) kemungkinan juga menyebabkan tidak terlihat perbedaan konsumsi perlakuan dengan kontrol. Serat kasar (SK) tertinggi 4,32\% pada ransum dengan porsi DDGS 30\% masih dapat ditoleransi oleh saluran pencernaan puyuh jantan, karena kandungan SK ransum masih di bawah kandungan maksimum yang diperbolehkan. Ransum puyuh tidak boleh mengandung SK melebihi 7\% karena SK bersifat bulky dan mempengaruhi konsumsi protein (Anonimus, 2006). Adapun konsumsi protein yang didapat saat penelitian tertera pada Tabel 3 .

Analisis statistik menunjukkan bahwa penggunaan DDGS hingga 30\% tidak mempengaruhi konsumsi protein dan energi. Tillman et al. (1998) menyatakan bahwa besar kecilnya konsumsi ransum akan mempengaruhi konsumsi protein ternak. Konsumsi protein ini yang nantinya bertanggung jawab pada kenaikan berat badan ternak. Adapun konsumsi protein dapat didefinisikan sebagai banyaknya protein kasar yang ada pada sejumlah ransum yang dikonsumsi. Rata-rata konsumsi protein puyuh jantan penelitian adalah $2,80 \pm 0,13$ g/ekor/hari (Tabel 3). Angka ini sesuai dengan penelitian Elfawati (2006) yang menyatakan bahwa rerata konsumsi puyuh adalah $2,80 \mathrm{~g} / \mathrm{ekor} / \mathrm{hari}$.

Kandungan protein kasar dalam pakan menurut Zuprizal (2006) tidak memberikan satu

Tabel 2. Performan puyuh jantan umur 35 hari (performance of 35 day old male coturnix)

\begin{tabular}{|c|c|c|c|c|}
\hline \multirow{2}{*}{ Parameter } & \multicolumn{4}{|c|}{ Perlakuan (treatments) } \\
\hline & $\mathrm{P}_{0}$ & $\mathrm{P}_{1}$ & $\mathrm{P}_{2}$ & $\mathrm{P}_{3}$ \\
\hline Berat badan (g/ekor) (body weight (g/head) $)^{\mathrm{ns}}$ & $124,49 \pm 6,14$ & $125,3 \pm 5,18$ & $127,56 \pm 4,08$ & $122,99 \pm 7,30$ \\
\hline $\begin{array}{l}\text { Konsumsi pakan (g/ekor) (feed intake } \\
(\mathrm{g} / \mathrm{he} a d))^{\mathrm{ns}}\end{array}$ & $284,47 \pm 17,05$ & $279,84 \pm 15,54$ & $291,29 \pm 13,73$ & $288,85 \pm 16,39$ \\
\hline $\begin{array}{l}\text { Pertambahan bobot badan (g/ekor) (body } \\
\text { weight gain }(\mathrm{g} / \mathrm{head}))^{\mathrm{ns}}\end{array}$ & $75,79 \pm 5,96$ & $76,68 \pm 9,34$ & $82,87 \pm 5,98$ & $76,28 \pm 7,97$ \\
\hline FCR (feed conversion ratio $)^{\mathrm{ns}}$ & $3,77 \pm 0,30$ & $3,68 \pm 0,36$ & $3,53 \pm 0,23$ & $3,81 \pm 0,25$ \\
\hline Mortalitas (mortality) & $0 / 40$ & $1 / 40$ & $1 / 40$ & $0 / 40$ \\
\hline
\end{tabular}

Tabel 3. Rerata konsumsi protein dan energi puyuh jantan umur 15-35 hari (average daily protein and energy intake of 15-35 day old male cortunix)

\begin{tabular}{|c|c|c|c|c|}
\hline \multirow{2}{*}{ Parameter } & \multicolumn{4}{|c|}{ Perlakuan (treatments) } \\
\hline & $\mathrm{P}_{1}$ & $\mathrm{P}_{2}$ & $\mathrm{P}_{3}$ & $\mathrm{P}_{4}$ \\
\hline $\begin{array}{l}\text { Konsumsi protein (g/ekor/hari) (protein intake } \\
(\mathrm{g} / \text { head/dav) })^{\mathrm{ns}}\end{array}$ & $2,88 \pm 0,08$ & $2,72 \pm 0,15$ & $2,83 \pm 0,04$ & $2,79 \pm 0,16$ \\
\hline $\begin{array}{l}\text { Konsumsi energi (kkal/ekor/hari) (energy intake } \\
\left(\text { (kcal/head/dav) }^{\mathrm{ns}}\right.\end{array}$ & $42,29 \pm 1,11$ & $40,75 \pm 2,26$ & $42,51 \pm 0,61$ & $41,80 \pm 2,37$ \\
\hline
\end{tabular}


efek yang cukup berarti terhadap konsumsi pakan. Perubahan kandungan protein kasar dalam pakan dapat mempengaruhi performan produksi dan akhirnya akan berpengaruh terhadap kebutuhan energi, jadi jika terjadi perubahan konsumsi pakan adalah disebabkan secara tidak langsung oleh perubahan kandungan protein pakan. Bila persentase protein sama di dalam semua pakan, maka pakan yang mempunyai ME tinggi akan menyediakan ketersediaan protein yang kurang dalam tubuh unggas karena rendahnya jumlah makanan yang dikonsumsi. Sebaliknya, bila kadar energi kurang maka unggas akan mengkonsumsi makanan untuk mendapatkan lebih banyak energi akibatnya kemungkinan akan mengkonsumsi protein yang berlebihan (Tillman et al., 1998).

Ternak yang sedang tumbuh memerlukan energi untuk pemeliharaan tubuhnya, pemeliharaan tubuh terutama dalam pemeliharaan jaringanjaringan tubuh yang dibentuk. Energi ini didapat dari pakan yang dimakan. Pada unggas yang sedang tumbuh, apabila kebutuhan energi sudah tercukupi, maka kelebihan protein kasar dalam pakan dapat menurunkan sedikit nafsu makan tanpa mempengaruhi pertumbuhan unggas tersebut. Apabila ternak makan protein yang melebihi kebutuhan, sisanya tidak dapat digunakan sebagai sumber protein, karena terjadi proses deaminasi asam amino di dalam hati untuk digunakan sebagai sumber energi (Perry, 1999).

Hasil penelitian menunjukkan tidak adanya pengaruh penambahan DDGS hingga level 30\% dalam pakan. Hal ini diduga terjadi karena tidak adanya perbedaan kandungan konsumsi protein dan energi antar pakan perlakuan (Tabel 3). Konsumsi energi yang sama menyebabkan pertumbuhan cenderung sama. McDonald et al. (2002) menyatakan bahwa asupan energi dalam pakan berguna untuk pertumbuhan dimanfaatkan secara maksimal oleh tubuh untuk hidup pokok dan pertumbuhan di samping untuk kelangsungan hidup ternak. Selain energi, juga dibutuhkan asupan protein yang sesuai. Tingkat pemberian protein yang sama dalam pakan akan memberikan pengaruh pertumbuhan yang sama (Colin et al., 2004).

Uji statistik menunjukkan bahwa FCR puyuh yang diberi perlakuan DDGS sampai 30\% tidak menunjukkan perbedaan dibanding dengan pakan kontrol (Tabel 1). Rata-rata nilai FCR yang terendah didapat pada perlakuan $\mathrm{P}_{2}$ (DDGS 20\%)

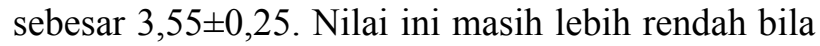
dibanding dengan hasil penelitian Chimote et al. (2009) yang menyebutkan bahwa nilai FCR puyuh pedaging umur 35 hari adalah 3,32. Meskipun belum mampu menurunkan nilai FCR, akan tetapi hal ini bisa dikatakan baik, karena Tangendjaja (2008) menyatakan bahwa pemakaian DDGS sampai $30 \%$ pada pakan broiler dapat menyebabkan naiknya nilai FCR kecuali hanya diberikan pada minggu terakhir sebelum panen.

Efisiensi pakan yang berbeda tidak nyata bisa disebabkan karena penggunaan DDGS pada pakan belum bisa mempengaruhi nilai kecernaan dari pakan perlakuan, sehingga protein yang tercerna keempat perlakuan kemungkinan hampir sama, juga dapat disebabkan karena keseimbangan asam amino dari protein pakan yang belum membaik, sehingga akan menyebabkan sintesis protein dalam tubuh juga hampir sama. Syarat utama terjadinya sintesis protein harus tersedianya asam-asam amino bebas dalam jumlah yang berbeda untuk masing-masing asam amino bila tidak sintesis dapat tertunda. Menurut McGilvery dan Goldstein (1996) pada saat protein pakan dihidrolisis di dalam usus dan membebaskan asam amino penyususunnya, sebagian protein jaringan tubuh juga terhidrolisis menjadi asam amino bebas. Asam amino dari ke dua sumber ini akan membentuk suatu tampungan (pool) asam amino dalam cairan ekstra sel yang dapat diambil jaringan tubuh untuk digunakan membentuk senyawa bernitrogen termasuk protein.

\section{Kesimpulan}

DDGS dapat digunakan sampai dengan level $30 \%$ dalam pakan puyuh jantan.

\section{Daftar Pustaka}

Anonimus. 2006. SNI 01-3905-2006 Pakan anak puyuh. Available at http://www.scribd.com/ doc/60400688/Sni-Pakan-Anak-puyuh.

Accession date: $13 \mathrm{Mei}, 2012$.

Arora, S., M. Wu and M. Wang. 2008. Update of Distiller Grains 'Displacement Rations for Corn Ethanol Life-Cycle Analysis. Center for transportation Research energy System Division Argonne National Laboratory. UChicago Argonne, Illinois 60439.

Babcock, B. A., D. J. Hayes and J. D. Lawrence. 2008. Using Distillers Grains in the U.S. and International Livestock and Poultry Industries. Center of Agricultural and Rural Development. Iowa State University, A.S.

Batal, A. B. 2009. Use of by-products from the biofuels industry and other alternatives to replace corn in poultry diets. Iowa State University Animal Industry, A.S. Available at http://www.thepoultrysite.com/articles/ 1324/use-of-byproducts-from-the-biofuelsindustry-and-other-alternatives-to-replacecorn-in-poultry-diets. Accession date: $29^{\text {th }}$ September, 2011. 
Chimote, M. J., B. S. Barbamase, A. S. Raut, A. P. Dhok and S. V. Hurakar. 2009. Effect of supplementation of probiotic and enzymes on performance of japanese quail. Veterinary World 2: 219-220.

Colin, G. S., G. Branbt and M. E. Ensminger. 2004. Poultry Science. $4^{\text {th }}$ ed. Pearson Education. Inc., New Jersey.

Dale, N. M. 2007. Biofuels and poultry production. Iowa state university animal industry, A.S. Available at http://www.thepoultrysite.com/ articles/852/biofuels-and-poultry-production. Accession date: $29^{\text {th }}$ September, 2011.

Elfawati. 2006. Pengaruh pemakaian tepung umbi talas (Xanthosoma sagitifolium) dan penambahan metionin dalam ransum puyuh periode pertumbuhan. Jurnal Peternakan 3: 10-17.

Houndonougbo, F. M., A. Chwalibog and C. A. A. M. Chrysostome. 2009. Is the nutritional value of grains in broiler chickens' diets affected by environmental factors of soybean (Glycine max) growing and the variety of maize (Zea maize) in Benin. Livestock Research for Rural Development 21. Available at http://www.Irrd.org/Irrd21/2/ cont2012.htm. Accession date: $29^{\text {th }}$ September, 2011.

Khan, M. Y., T. N. Pasha, A. Khalique, Z. Ali and H. Rehman. 2002. Effect of feeding hydrogen peroxide treated defatted rice polishing on performance of broiler chicks. Poult. Sci. 1: 193-196.

McDonald, P., R. A. Edwards, J. F. D. Greenhalgh and C. A. Morgan. 2002. Animal Nutrition. $6^{\text {th }}$ edition, Pearson Education Limited, Harlow, USA.

Perry, T. W., A. E. Cullison and R. S. Lowrey. 1999. Feed and Feeding. $4^{\text {th }}$ ed. Prentice Hall, New Jersey.
Shalash, S. M. M., S. Abou El-Wafa, R. A. Hassan and N. A. Ramadan. 2010. Evaluation of distillers dried grains with solubles as feed ingredient in laying hen diets. Poult. Sci. 9: 537-545.

Smith, M. O., K. Soisuvan and L. C. Miller. 2003. Evaluation of dietary calcium level and fat source on growth performance and mineral utilization of heat-distressed broilers. Poult. Sci. 2: 32-37.

Smith, T. W. 2011. How to feed quail and quail nutrition. Publication 2383. Extension Service of Mississippi State University, cooperating with U.S. Department of Agriculture. Available at: http://poultryone. com/articles/feedingquail.html. Accession date: $29^{\text {th }}$ September, 2011.

Tangendjaja, B. 2008. Destiller's dried grains with solubles (DDGS) untuk pakan. Wartazoa. Buletin Ilmu Peternakan Indonesia 18: $137-$ 148.

Tillman, A. D., H. Hartadi, S. Reksohadiprodjo, S. Prawirokusumo and S. Lebdosukojo. 1998. Ilmu Makanan Ternak Dasar. Cetakan ke 6. Gadjah Mada University Press. Yogyakarta.

Wang, Z., S. Cerrate, C. Coto, F. Yan and P. W. Waldroup. 2007. Utilization of distillers dried grains with solubles (DDGS) in broiler diets using a standardized nutrient matrix. Poult. Sci. 6: 470-477.

Watkins, S. E., E. A. Saleh and P. W. Waldroup. 2002. Reduction in dietary nutrient density aids in utilization of high protein cottonseed meal in broiler diets. Poult. Sci. 1: 53-58.

Zuprizal. 2006. Nutrisi Unggas. Fakultas Peternakan Universitas Gadjah Mada, Yogyakarta. 